\title{
PENDIDIKAN POLITIK PEMILIH MUDA DALAM PEMILIHAN KEPALA DESA SERENTAK DI KABUPATEN BANDUNG TAHUN 2019
}

\author{
DEWI KURNIASIH \\ Program Studi Ilmu Pemerintahan, Universitas Komputer Indonesia \\ e-mail :dewi.kurniasih@email.unikom.ac.id
}

\begin{abstract}
Young voters in the head of village election simultaneously 2019's are a new generation of voters who have different characteristics and characters, backgrounds, experiences and challenges from the previous generation of voters. Most of them come from among students, have good economic status, and generally live in urban or surrounding areas. They are very open to learning new, critical and independent things. The contribution of young voters in the field of village politics is based on the role of youth as controlling agents. Young voters, especially in villages, can provide insight to village communities regarding the head of village elections so that the community can actively participate in village head elections in order to minimize abstentions. The role of political education for young voters is very important to be implemented in achieving a high level of success in the head of village election simultaneously in Bandung Regency in 2019.
\end{abstract}

Key words: political education, young voters, the head of village election

\begin{abstract}
ABSTRAK
Pemilih muda pada pilkades serentak di Kabupaten Bandung tahun 2019 adalah generasi baru pemilih yang memiliki sifat dan karakter, latar belakang, pengalaman dan tantangan yang berbeda dengan para pemilih generasi sebelumnya. Sebagian besar di antara mereka berasal dari kalangan pelajar, berstatus ekonomi baik, dan pada umumnya tinggal di kawasan perkotaan atau sekitarnya. Mereka sangat terbuka untuk mempelajari hal-hal yang baru, kritis dan juga mandiri. Kontribusi pemilih muda dalam bidang politik desa berlandaskan atas peran pemuda sebagai Agen controlling. Pemilih muda terutama di desa dapat memberikan wawasan kepada masyarakat desa terkait pemilihan kepala desa agar masyarakat dapat turut aktif berpartisipasi dalam pemilihan kepala desa guna meminimalisir golput. Peran pendidikan politik bagi pemilih muda sangat penting untuk dilaksanakan dalam mencapai tingkat kesuksesan yang tinggi pada pilkades serentak di Kabupaten Bandung Tahun 2019.
\end{abstract}

Kata kunci: pendidikan politik, pemilih muda, pemilihan kepala desa 


\section{PENDAHULUAN}

Kabupaten Bandung menjadi salah satu kabupaten di Jawa Barat yang menyelenggarakan pilkades serentak pada tanggal 26 Oktober 2019. Sebanyak 199 desa di Kabupaten Bandung menyelenggarakan pemilihan kepala desa (pilkades) serentak tersebut. Pelaksanaan pilkades serentak 2019 di Kabupaten Bandung ini, di antaranya ada yang habis masa jabatan kepala desanya sejak 2018 lalu, yaitu 64 desa. Pada 2019, sebanyak 124 desa dan pada 2020 sebanyak 11 desa. 11 desa itu, 7 desa habis masa jabatan kepada desanya pada Januari 2020, 3 desa Februari 2020 dan 1 desa pada Mei 2020.

Pemerintah Kabupaten Bandung memiliki jumlah pemilih pemula yang cukup banyak yaitu sebanyak sepuluh persen dari jumlah pemilih pilkades serentak. Sebutan pemilih pemula ini dikenal juga dengan istilah pemilih muda. Menurut The Pew Research Center dan Gallup pemilih muda adalah orang yang memiliki hak untuk memberikan suara dalam pemilihan umum yang berusia antara 17 sampai dengan 29 tahun.

Pemilih muda pada pilkades serentak di Kabupaten Bandung tahun 2019 adalah generasi baru pemilih yang memiliki sifat dan karakter, latar belakang, pengalaman dan tantangan yang berbeda dengan para pemilih generasi sebelumnya. Sebagian besar di antara mereka berasal dari kalangan pelajar, berstatus ekonomi baik, dan pada umumnya tinggal di kawasan perkotaan atau sekitarnya. Kelompok ini sangat tersentuh kemajuan teknologi informasi, mereka menggunakan alat-alat teknologi canggih dengan baik, mulai dari handphone, laptop, ipod, ipad, tablet dan aneka gadget lainnya. Mereka juga sangat fasih dalam penggunaan fasilitas dan jaringan sosial media, seperti, internet, twitter, facebook, linked in, dan sebagainya. Mereka sangat terbuka untuk mempelajari hal-hal yang baru, kritis dan juga mandiri. Kelompok pemilih muda menghadapi tantangan yang sangat berat, mulai dari perubahan politik dan permasalahan dalam negeri yang tidak kunjung jelas arah penyelesaiannya hingga tekanan-tekanan globalisasi, perdagangan bebas, terorisme, intervensi internasional, dan sebagainya.

Salah satu yang dapat menjadi perhatian khusus adalah pendidikan politik yang masih rendah di kalangan pemilih muda. Oleh karena itu, pendidikan politik itu sangat penting dengan berlandaskan pada Pasal 31 UndangUndang No. 22 Tahun 2008 tentang Fungsi Partai Politik untuk memberikan pendidikan politik diantaranya:

1. Meningkatkan kesadaran hak dan kewajiban masyarakat dalam kehidupan bermasyarakat, berbangsa, dan bernegara.

2. Meningkatkan partisipasi politik dan inisiatif masyarakat dalam kehidupan bermasyarakat, berbangsa, dan bernegara.

3. Meningkatkan kemandirian, kedewasaan, dan membangun kesatuan bangsa dalam rangka memelihara persatuan dan kesatuan Negara.[1]

Istilah Pendidikan Politik berasal dari bahasa inggris yaitu Political socialization. Apabila ditelusuri pada berbagai literatur politik yang ada Pendidikan Politik termasuk bagian proses sosialisasi politik. Walaupun berbeda secara penulisan,baik sosialisasi politik maupun pendidikan politik mempunyai tujuan serta fungsi yang sama secara prinsip. Baik sosialisasi politik ataupun pendidikan politik dipergunakan bersama tanpa diperdebatkan. [2]

Pendidikan politik yaitu untuk meningkatkan pengetahuan rakyat agar mereka dapat berpartisipasi secara maksimal dalam sistem politiknya. Sesuai paham kedaulatan rakyat atau demokrasi rakyat harus mampu menjalankan tugas partisipasi.

Pendidikan politik pada dasarnya adalah melakukan rekonstruksi atas nilai-nilai yang selama ini ada dan membangun nilai-nilai baru. Lazimnya pendidikan, ini menyediakan proses transformasi pengetahuan, pembentukan sikap- sikap tertentu dan perubahan-perubahan perilaku yang dituju. Aspek pertama, menyangkut dimensi kognitif, sedangkan aspek kedua dan ketiga merupakan aspek afektif dan behavioristik. Dengan demikian pendidikan politik memiliki makna penting dan strategis, yang menggerakan warga negara (para pemilih) memiliki 
pengetahuan politik yang memadai, sekaligus kesadaran akan pentingnya sistem politik yang ideal serta perilaku politik yang cerdas dan kritis.[3]

Jumlah pemilih pemula sebanyak sepuluh persen tersebut sangat besar dan signifikan. Mengingat karakteristik generasi muda yang berbeda. Oleh karenanya, diperlukan sebuah pendekatan khusus dalam merubah persepsi negatif, merubah sikap apatis dan pragmatis terhadap pilkada menjadi positif, aktif dan partisipatif. Pendekatan khusus ini diperlukan karena pemilih muda adalah sosok yang cenderung berpikiran terbuka, kritis, mampu beradaptasi dengan cepat terhadap perkembangan teknologi informasi, dan terlatih berpikir mandiri. Perilaku keseharian mereka pun cenderung lebih menggunakan kemampuan visual dalam menerima dan menyampaikan informasi. Guna menelusuri kelompok ini, dibutuhkan pendekatan khusus. Pendekatan khusus yang dimaksud adalah dengan memanfaatkan metode budaya populer, menggunakan media sosial dan disampaikan secara interaktif dan informatif.

\section{METODE PELAKSANAN}

Metode pelaksanaan kegiatan pendidikan politik dilaksanakan oleh Badan Kesatuan Bangsa dan Politik Kabupaten Bandung dengan tema "Peran Generasi Muda dalam Menghadapi Pilkades Serentak di Kabupaten Bandung". Kegiatan tersebut dilaksanakan di Aula R.M. Sukahati Kabupaten Sumedang yang berada di Jl. Cipacing KM. 19,6 Cileunyi pada tanggal 28 Agustus 2019 dimana pesertanya adalah para pemuda yang tergabung dalam karang taruna di beberapa desa di Kecamatan Cicalengka dan Rancaekek Kabupaten Bandung.

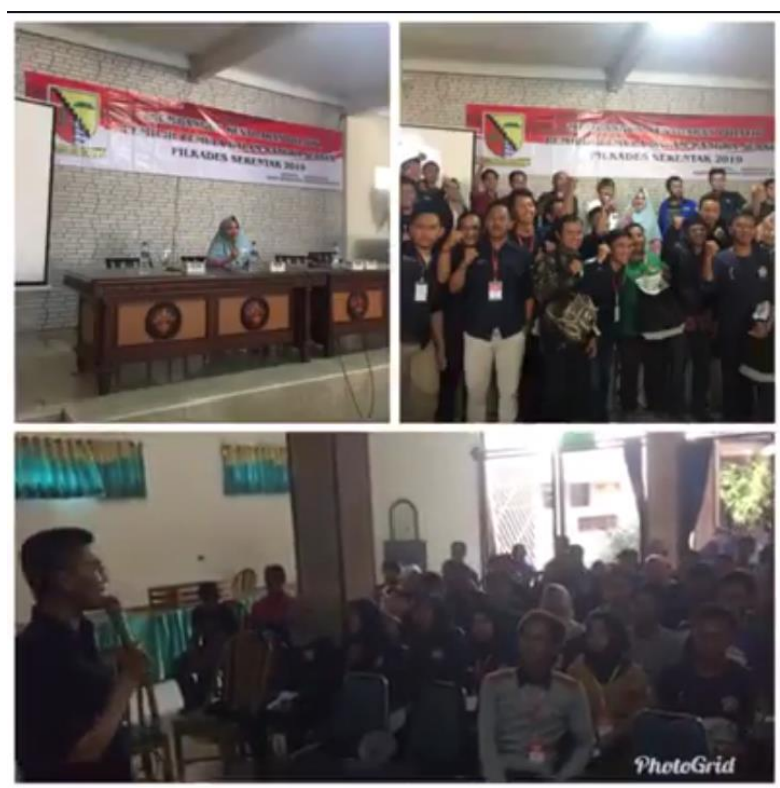

Gambar 1. Pendidikan Politik Bagi Organisasi Kemasyarakatan Tingkat Kabupaten Bandung, Kesbangpol Kabupaten Bandung, Agustus 2019

Pelaksanaan kegiatan pendidikan politik lainnya dilaksanakan oleh Badan Kesatuan Bangsa dan Politik Kabupaten Bandung masih dengan tema yang sama "Peran Generasi Muda dalam Menghadapi Pilkades Serentak di Kabupaten Bandung". Kegiatan tersebut dilaksanakan di Aula Hotel Abang yang berada di Jalan Raya Ciwidey - Patenggang No. 500 KM.2 Kecamatan Ciwidey Kabupaten Bandung pada tanggal 24 September 2019 dengan peserta pemuda dari beberapa desa di Kecamatan Ciwidey.

Pelaksanaan kegiatan pendidikan politik lainnya dilaksanakan oleh Badan Kesatuan Bangsa dan Politik Kabupaten Bandung dengan tema "Pendidikan Politik Bagi Organisasi Kemasyarakatan Tingkat Kabupaten Bandung”. Aula R.M. Ampera yang berada di Jalan Jl. Gading Tutuka 1 Soreang Kabupaten Bandung pada tanggal 18 Oktober 2019. 


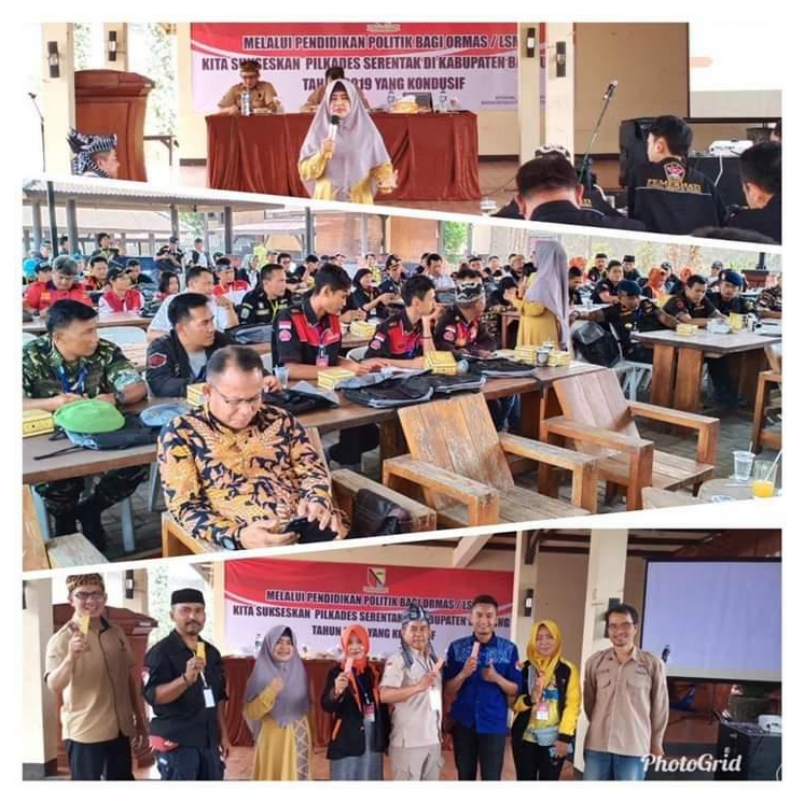

Gambar.1 Pendidikan Politik Bagi Organisasi Kemasyarakatan Tingkat Kabupaten Bandung, Kesbangpol Kabupaten Bandung, Oktober 2019.

Dalam kegiatan pendidikan politik yang diselenggarakan oleh Badan Kesatuan Bangsa dan Politik Kabupaten Bandung diharapkan bahwa keberhasilan pelaksanaan penyelenggaraan pilkades perlu adanya pengetahuan politik generasi muda dalam penyelenggaraan pilkades serentak di kabupaten bandung dan fenomena golput berkurang terutama di kalangan generasi muda.

\section{HASIL DAN PEMBAHASAN}

Pemilihan kepala desa (Pilkades) dianggap sebagai arena demokrasi yang paling nyata di desa. Dalam Pilkades terjadi kompetisi yang bebas, partisipasi masyarakat, pemilihan secara langsung dengan prinsip one man one vote.

Pilkades menjadikan suasana demokrasi didesa-desa di suatu kabupaten dirasakan lebih hidup dan dapat memacu tingkat partisipasi masyarakat yang sangat tinggi. Golput boleh dikatakan tidak ada. Justru masyarakat yang tidak bisa menggunakan hak pilihnya banyak yang mengeluh karena waktu pencoblosan mereka berhalangan karena bekerja atau sedang bepergian ke luar daerah. Hal ini menandakan kesadaran politik masyarakat desa sudah sangat tinggi.[4]

Salah satu kelompok partisipan dalam pilkades adalah kelompok pemilih pemula atau pemilih muda. Partisipasi generasi muda dalam praktik politik dan demokrasi merupakan poin penting dalam penyelenggaraan kehidupan berbangsa dan bernegara. Pemilihan umum menjadi ajang bagi setiap warga negara untuk menyalurkan hak nya dalam biddang politik untuk memilih penyelenggara ini.[5]

Batasan, perbedaan sifat dan karakter, latar belakang, pengalaman dan tantangan para pemilih muda pada pilkades serentak 2019 perlu dipahami dengan baik, terutama untuk mempersiapkan pemilih muda yang cerdas, kritis dan berorientasi masa depan. Ditambah dengan fakta bahwa para pemilih muda ini adalah pengemban tampuk pimpinan selanjutnya pada saat 100 Tahun Republik Indonesia di tahun 2045 nanti. Republik Indonesia masih akan tetap ada (exist) di waktu tersebut akan sangat ditentukan oleh para pemilih muda ini.

Pemilih pemula yang terdiri atas pelajar, mahasiswa atau pemilih dengan rentang usia 17-21 tahun menjadi segmen yang memang unik, seringkali memunculkan kejutan dan tentu menjanjikan secara kuantitas. Disebut unik, sebab perilaku pemilih pemula dengan antusiasme tinggi, relatif lebih rasional, haus akan perubahan dan tipis akan kadar polusi pragmatisme.[6]

Batasan pemuda disini dimulai dari usia 16 tahun mengikuti penetapan umur anak muda yang dilakukan oleh Perserikatan Bangsa- Bangsa, sedangkan batas umur anak muda sampai 30 tahun didasari oleh UU Kepemudaan No. 40 tahun 2009 pasal 1 tentang : Pemuda adalah warga negara Indonesia yang memasuki periode penting pertumbuhan dan perkembangan yang berusia 16 (enam belas) sampai 30 (tiga puluh) tahun. Pemilih muda ini dapat menjadi kekuatan tersendiri dalam pemilu, antusias kelompok ini cukup tinggi dan mayoritas kelompok ini ingin memberikan suaranya pada setiap pemilu yang ada.[1] 
Di dalam UU tersebut disebutkan bahwa peran aktif pemuda sebagai agen perubahan yang diwujudkan dengan mengembangkan salah satunya adalah pendidikan politik dan demokratisasi.

Pengaruh pemilih muda yang penting dan signifikan pada pelaksanaan pilkades serentak 2019. Salah satu yang harus menjadi perhatian khusus adalah pendidikan politik yang masih rendah di kalangan pemilih muda. Pendidikan politik yang masih rendah membuat kelompok ini rentan dijadikan sasaran untuk dimobilisasi oleh kepentingankepentingan tertentu.

Oleh karena itu, dengan berlandaskan motivasi untuk mempersiapkan masa depan bangsa dan negara serta untuk menjaga agar pemilihan umum ke depan dapat berjalan dengan baik, dan menghasilkan output yang memiliki legitimasi untuk memimpin pemerintahan, maka program pendidikan politik untuk pemilih muda sangat penting dan mendesak untuk dilakukan.

Betapa pentingnya pendidikan politik karena terkait dengan aspek sikap dan perilaku. Sehingga dibutuhkan sumbangsih dan peran besar dari generasi muda bangsa tentunya mempengaruhi kehidupan politik bangsa dan negara yang saat ini penuh dengan tantangan. Sebagai generasi penerus bangsa atau angkatan muda yang memiliki pendidikan dan sebagai kaum intelektual sudah sepantasnya memiliki dasar pengetahuan mengenai kehidupan politik bangsanya.[7]

Agar dapat lebih efektif, program pendidikan politik tersebut perlu dilaksanakan dengan cara dan metode khusus serta dengan materi dan kurikulum yang disesuaikan dengan karakter, kebutuhan, kepentingan, minat dan tingkat pengalaman dan pemahaman mereka tentang politik.

Beberapa hal yang dapat dilakukan oleh para genrasi muda sebagai terobosan dalam politik terutama pilkades serentak 2019 di Kabupaten Bandung yaitu: pertama adalah menghilangkan politik uang dalam pilkades. Generasi muda sebagai leader of change dapat turut andil dalam menanamkan stigma kepada masyarakat bahwa pilkades serentak ini harus dilakukan secara sehat tanpa adanya politik uang ataupun uang sogokan saat pencoblosan. Hal tersebut bukan berarti bahwa para calon kepala desa tidak memberikan uang kepada masyarakat itu pelit karena tidak mau berbagi kepada masyarakat, melainkan karena para calon kepala desa menjunjung nilai-nilai kejujuran dan keadilan.

Kedua, mencegah terjadinya kampanye negative (Stop Black Campaign). Generasi muda disini sebagai leader of change, dimana para generasi muda memiliki peran yang sangat penting dalam menggiring opini masyarakat dan media dalam mewujudkan pilkades yang sehat. Hal tersebut dapat mengurangi terjadinya serang argumen antar supporter calon Kepala Desa baik di dunia maya (sosial media) maupun di dunia nyata.

Generasi Muda menjadi kunci kemenangan, sekaligus membawa semangat Pilkades serentak 2019 di Kabupaten Bandung menjadi pesta demokrasi yang cerdas, santun dan beradab.

Pemerintah Kabupaten Bandung melalui Badan Kesatuan Bangsa dan Politik menyelenggaraan kegiatan pendidikan politik bagi generasi muda tingkat Kabupaten Bandung yang bekerjasama dengan berbagai Perguruan Tinggi. Penyelenggaraannya dilakukan melalui beberapa tahap dengan peserta dari beberapa desa pada masingmasing kecamatan di wilayah Pemerintah Kabupaten Bandung.

\section{KESIMPULAN}

Pendidikan politik yang diselenggarakan dalam rangka meningkatkan partisipasi pemilih muda dalam pilkades serentak 2019 ini bisa bekerjasama antara berbagai perguruan tinggi dengan Komisi Pemilihan Umum Daerah (KPUD) Kabupaten Bandung. Kegiatan ini sangat bermanfaat untuk menarik minat para pemilih muda khususnya di Kabupaten Bandung untuk dapat menggunakan hak suaranya dalam pilkades serentak 2019 dengan melihat visi, misi serta program yang dibawa oleh masing-masing calon kepala desa. Pendidikan politik sangat positif, dan perlu diselenggarakan dalam setiap pemilihan umum. 


\section{UCAPAN TERIMA KASIH}

Ucapan terima kasih kami sampaikan kepada Pemerintah Kabupaten Bandung khususnya Kepala Badan Kesatuan Bangsa dan Politik yang telah mendanai kegiatan ini serta Direktur LPPM Unikom yang telah memberikan ijin kepada kami untuk melaksanakan pengabdian pada masyarakat ini.

\section{DAFTAR PUSTAKA}

[1] D. Kharisma, "Peran Pendidikan Politik Terhadap Partisipasi Politik Pemilih Muda," J. Polit., vol. 1, no. 7, 2015.

[2] A. V. Wanma, "Pentingnya Pendidikan Politik Generasi Muda Terhadap Pelaksanaan Partisipasi Politik Di Distrik Samofa Kabupaten Biak Numfor," J. Polit., vol. 2, no. 6, 2015.

[3] A. Soeprapto, S. DN, and B. A. Suparno, "Komunikasi Dalam Proses Pendidikan Politik Pemilih Pemula Dalam Pemilihan Umum 2014 di DIY," J. Ilmu Komun., vol. 12, no. 1, pp. 3954, 2015.

[4] I. N. Tandanugi, "Budaya Politik Lokal Pada Pilkades di Kecamatan lage Kabupaten Poso Tahun 2010," Administratie, vol. 01, no. 4, pp. 36-40, 2015.

[5] Rohmat, A. M. Holish, and I. Syariefudin, "Pengaruh Pendidikan Politik dan Demokrasi Bagi Generasi Muda Terhadap Tingkat Partisipasi Pelaksanaan Pemilihan Umum," Semin. Nas. Huk. Univ. Negeri Semarang, vol. 4, no. 03, pp. 1191-1204, 2018.

[6] P. S. N. Wardhani, "Partisipasi Politik Pemilih Pemula dalam Pemilihan Umum," Jupiis J. Pendidik. Ilmu-Ilmu Sos., vol. 10, no. 1, p. 57, 2018.

[7] D. S. Rahmadi, "Peran Elit Politik Lokal dalam Pendidikan Politik Mahasiswa di Kabupaten Lombok Timur," SOCIO J. Ilmu-Ilmu Sos., vol. 15, no. 1, pp. 15-32, 2016. 